\title{
ヴィガン(イロコス，フィリピン)の街区構成に関する考察 BLOCK FORMATION IN VIGAN, ILOCOS, THE PHILIPPINES
}

\author{
山口潔子*, 布野修司**, 安藤 正雄***, 脇田祥尚****, 柳 沢 \\ Kiyoko YAMAGUCHI, Shuji FUNO, Masao ANDO, \\ Yoshihisa WAKITA and Kiwamu YANAGISAWA
}

究 $* * * * *$

\begin{abstract}
Vigan is one of the most preserved Spanish colonial towns in the Philippines. With numerous historical buildings and houses, UNESCO registered Vigan as the World Heritage in December 1999. As an entrepôt flourished by Chinese mestizo residents, Vigan forms an amalgam of native, Chinese and Spanish cultural landscape. The public spaces such as the poblacion (city center) strongly reflects Leyes de Indias (Laws of Indies) : plaza surrounded by cathedral, convent, city hall, and relatively grid street pattern.

Yet, deviation from the Spanish colonial city planning concept is visible, in comprising two main plazas, and in the indistinct racial residential separation. The paper is composed of : administration history of Vigan and the Philippines; reference to the Leyes de Indias colonial law and other Hispanized towns; and considerations on block formation, road width, and lot division in Vigan. In conclusion, this paper proposes $3 \times 3$ block subdivision style and the modified use of Spanish module system in Vigan.
\end{abstract}

Keywords : Vigan, street system, block formation, Spanish colonial city, Laws of Indies, World Heritage ヴィガン, 街路体系, 街区構成, スペイン植民都市, インディアス法, 世界遺産

\section{1. 研究の目的と背景}

本稿は，「植民都市空間の起源・変容・転成・保全に関する調査研 究」と題する研究の一環として,フィリピン，イロコス・スール州の ヴィガン Vigan 市を対象とし，その形成過程および変容過程につい て考察することを目的としている。

ヴィガンは，スペインによって，セブCebu(1565), パナイ Panay (1569)，マニラ Manila（1571）についで建設された植民都市である (図 1)。戦災等で大きくその骨格を変えたセブ，パナイ，そして近 年その都市核の一部イントラムロス Intramuros ${ }^{2}$ 復元されたマニ ラと異なり，ヴィガンはスペインによって建設されたアジアの植民 都市として，その当初の姿を今日に伝える興味深い都市である。そ の歴史的意義が評価され，ヴィガン中心部は1999年ユネスコによっ て世界文化遺産に指定されている。

本研究では，スペインの植民都市の理念がどのように東南アジア (フィリピン)にもたらされたのか，が大きな視点となる。具体的に は, インディアス法 ${ }^{3} と の$ 比較が課題となる。本稿では, まずヴィガ ンの歴史的概要をまとめた上で, 現地調查をもとにして, 街路体系, 街区構成，そして敷地割りを中心とした考察を行う。街区割りにつ いてはひとつの仮説を提出したい。

ヴィガンに関する既往の研究は極めて少ない。主要な参考文献は 末尾に示す通りである。フィりピンにおけるスペイン植民都市計画
の概要について

は, リードRobert

R. Reed (1978) がある。また，

歴史的住居バ ハイ・・バト bahay na bato ${ }^{4}$ については, フィリピン大学 の修士論文ラバ ン Fatima N. Rabang-Alonzo (1990)がある。 ヴィガンの歴史 についてはキン

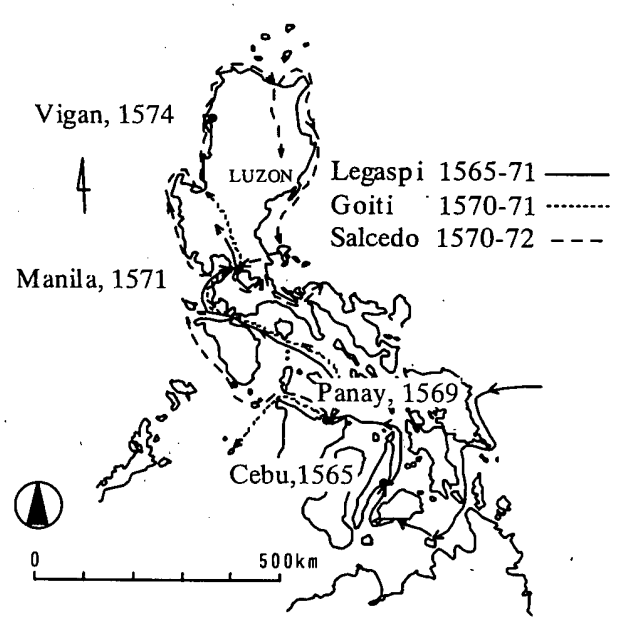

図 1 スペインのフィリピン植民地化の過程 （Reed（1978）を元に作成）
グ Damaso Q. King（1990）がある。

本稿のも之になる施設分布調査, 住宅類型調查および街区幅の測 定を主とする現地調查は1997年 7 月 (脇田祥尚)，1998年 9 月 (安藤 正雄，布野修司，脇田祥尚，柳沢究，平田隆行)，そして2000年 8 月 (山口潔子)の三次にわたる調査である。資料収集, 様々なヒアリン グについては，キング氏とラバン女史の協力を得た。

\footnotetext{
* 京都大学大学院アジア・アフリカ地域研究研究科 博士前期課程

** 京都大学大学院工学研究科 助教授.工博

****葉大学工学部 講師・工修

**** 島根女子短期大学 講師・工修

***** 京都大学大学院工学研究科 博士後期課程 $\cdot$ 工修

Graduate Student, Kyoto University

Assoc. Prof., Kyoto University, Dr. Eng.

Assist. Prof., Chiba University, M. Eng.

Lecturer, Shimane Women's College, M. Eng.

Graduate Student, Kyoto University, M. Eng.
} 


\section{2.ヴィガンの成立と都市形成}

フィリピンへ初めてのヨーロッパ人が訪れたのはセブにマゼラン Magellan の船団が到達した1521年のことである。しかし, マゼラン はセブ対岸のマクタン Mactan 島において殺されており, 都市建設 には到っていない。スペイン領有の端緒を開いたのは,メキシコ総

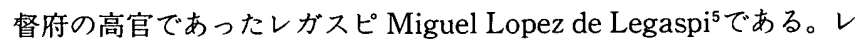
ガスピは1565年にサマール Samar 島からレイテ Leyte 島を経てセ プ島に至り，砦と居留地を建設した。その後，食糧不足やポルトガ ルによる脅威の為，69年にパナイ島に拠点を移した。この間，遠征 隊員を各地に派遣し，その報告に基づいて交易に有利なマニラを本 拠と決定した。当時のマニラは, 親族関係にある 2 人のムスリム王 がパシグ Pasig川を挟んでそれぞれに村を統治しており，木造の柴 があったとされる6。レガスピは，71年 5 月にマニラとその近郊トン ド Tondoの首長らと協定を結び，6月に砦の建設を開始した。 スペインはマニラを扰点としながら，各地に教会とプラサ plaza を建設し，そのまわりに現地住民を集住させ，市，プエブロ pueblo を編成した。この市には中心部カべセラ/ポブラシオン cabecera/ poblacion とその郊外の周辺村ヴィシタ visita が含まれた8。マニラ から北に $425 \mathrm{~km}$ 離れたイロコス地方のヴィガン9建設にあたったの は，レガスピの孫，サルセド Juan de Salcedoである。サルセドは 1567 年に物資・人員援助隊としてメキシコからセブにやって来た ${ }^{10}$ 。 1572年 5 月 20 日に, フィリピンーメキシコ間のより短い航路を求め て出航し，翌月にヴィガンに着いた。しばらく滞在したのち，27人 のスペイン人兵士を残し，ルソン島北部における新たなスペイン人 の拠点を求める探検に出た。その後，1574年 1 月にイロコス地方の

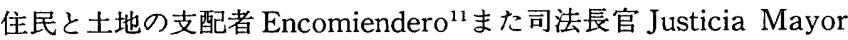
の地位をスペイン王から与えられ，ヴィガンに戻った ${ }^{12}$ 。サルセド は, 現地住民に森林を伐採させ，まず砦と宿泊施設 ${ }^{13}$, その後に教会, 市役所を建設した。1574年のサルセドのヴィガンへの帰還には，ア ウグスティノ修道会の宣教師たちが随行し ${ }^{14}$, 彼らは1575年 4 月に 聖パウロを町の守護聖人として教会と修道院を建設した。ヴィガン は,フェリぺ二世の王子にちなんでヴィジャ・フェルナンディーナ Villa Fernandina と名づけられた。

ヴィガンの歴史について書かれた資料はほとんどが教会資料であ る15。そうした記録によれば, 1579年, 中国人向かう途中であったフ ランシスコ修道会の宣教師たちの船が嵐によってイロコス地方に漂 着し, 宣教活動を行っている。フランシスコ会は宣教活動の便宜上, 点在していた村々を集め，宣教拠点である教会や修道院の周りに 人々を集住させ，新しく町をつくった。スペイン人植民者と宣教師 たちによるこの先住民の集住・移住計画はレドゥクシオン reducción と呼ばれた ${ }^{16}$ 。レドゥクシオンの結果, 自立的なバランガイ barangay ${ }^{17}$ から成っていた現地社会はスペインの統治機構の中に 組み込まれるが，これはまたカトリック教区司祭がスペイン植民地 権力の代表として日常生活のあらゆる面で住民を監視下に置くこと を意味した ${ }^{18}$ 。その後, 1591年に教会を修道会に所属しない司祭たち に託し，フランシスコ会はイロコス地方を去った。

17世紀初頭のヴィガンについてスペイン人官吏モルガ Antonio de Morga は「ヴィジャ・フェルナンディーナはルソン島北部イロコ

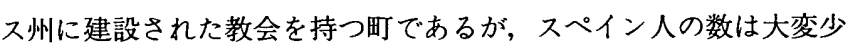
ない」と記している19。当時，マニラ以外のフィリピン地方都市は,
スペイン人の建設した町であっても，宣教師以外のスペイン人は少 なかったと言われている。

1613年のイロコス地方の司教記録によれば，当時ヴィガンの人口 は2000人であった。町が成長するにつれ，マニラと同様，人種別の 居住区が形成された。カトリック小教区によるヴィガン最古の史料 Libro de Casamiento(婚姻届録)に含まれる資料によれば，1645-60 年には，現地住民ナトゥラレス naturales 地区，スペイン人 españoles 地区, 中国人（主に福建省出身）のパリアンシリョ pariancillo ${ }^{20}$ 又はロス・サングレィス・デル・パリアン los sangleys del parian ${ }^{21}$ と呼ばれる地区に分かれていた22。ただ，プラサのある 中心部に宗教施設が集中していること, 現在のリサール Rizal 通り の東側がメスティソ地区, 西が現地住民地区とされていたことは記 されているが，かつての中国人地区やスペイン人地区の位置ははっ きりしていない23。

ルソン島北部においてヴィガンは最初のスペイン人町であった が，6人しか世俗スペイン人がいなかった時期もある。元々，北儿 ソン司教区の司教座と大聖堂を持っていたのは，港町でヴィガンよ り多くのスペイン人のいたカガヤン Cagayan 州の州都ヌエバ・セ ゴビア Nueva Segovia 市であった。しかし，邓エバ・セゴビアの 2 代目司教がヴィガンを好んだこともあり，1758年 9 月にスペイン王 室の承認をうけて，ヴィガンは新たにルソン島北部の司教座となっ た。教会が小教区教会から司教区聖堂に昇格したことに伴って,ヴィ ガンは行政上の町ヴィジャvillaから市シウダーciudadに昇格し た ${ }^{24}$ 。1764年のヴィガン市には21のバリオ barrio ${ }^{25}$ があったが，その いくつかは18世紀中に市から分離し，新しく町になった。

1803 年には人口 10,585 人を数之, 先住民は農業に, 中国人と中国 系メスティソ（中国人男性と現地住民女性の混血）はマニラ, ヨー ロッパ，中国，ボルネオ，マレーシアとの交易に従事し，ヴィガン 中心地域を経済的に興隆させた。19世紀中ごろには海外輸出物産と して，イロコス地方の米・藍・タバコ・綿織物が注目を浴び26, その 利益をもとにして煉瓦や瓦を使用した豪勢な住宅がヴィがンに增え た。その都市型住居をバハイ・ナ・バトという ${ }^{27}$ 。今日，町の中心部に おいて歴史的町並みを構成するバ八イ・ナ・バトを建てたのは，スぺ イン人・スペイン系メスティソではなく, 中国系メスティソであった。

\section{3. ヴィガンの都市構造}

\section{3-1 スペイン植民都市計画とフィリピン都市}

スペイン植民都市は，一般的にプラサを中心として格子状に街区 が形成され，プラサは教会・行政施設・スペイン人指導階層の住宅 などに取り囲まれる ${ }^{28}$ 。この都市計画の理念, 方法を考察する上で, まず想起されるのが中南米のスペイン植民都市の計画指針となった 1573年のインディアス法である。

フェリペII世のインディアス法が公布された1573年は，植民都市 マニラの建設開始の 2 年後であり, ヴィガン建設開始とほほ同時期 である。スペインの文書がフィリピンへ渡るのは, 貿易風を利用し た年 1 回のガレオン船によってのみであったことを考えると、マニ ラやヴィガンの建設当初から，1573年インディアス法の都市計画方 針がそのまま生かされたとは考えにくい。また，1573年のインディ アス法に含まれる都市計画の方針がフィリピンでも適用されたとい う明確な記録は無い。 
しかし，1573年以前から，一定の指針に基づいて中南米のスペイ ン植民都市の計画が行われており，1573年のインディアス法はその 経験を集大成したものである。フィりピンで建築・都市計画の指導 を実際に行った修道士たちは，メキシコでの宣教活動を経て来た者 たちであること ${ }^{29}, \cdot 1573$ 年のインディアス法がこの中南米での数々 の先例に基づいていることから，インディアズ法はフィリピンでの 植民都市計画史を見るうえでも極めて重要である。

フィリピンにも「町が市に昇格しスペイン帝国の副王領下の機構 に組み込まれ承認されるためには，スペイン王室の法令の基準を満 たさなければいけない」という指令は伝わっており，その記録もあ る ${ }^{30}$ 。その基準はインディアス法の都市計画の構成要素とほぼ重 なっている。ヴィガンについての資料はないが，ルソン島でヴィガ ンとマニラの間に位置するパンガシナン Pangasinan 州における都 市計画基準がある。市としての承認を受けるための条件が, マニラの サント・ドミンゴ司祭館所蔵の「1840年パンガシナン州に公布された スペイン王室法令 Real Cédula」として以下のように記されている。

「市の中心部となるべき地区の地理的・環境的考察が必要である。 市中心部は洪水の恐れが少ない場所が選ばれるべきである。また中 心部にはプラサ・教会・市役所・司祭館・学校を配置する。町が市 に承認される前に政治的・宗教的活動が可能となる公共建築が建ち あがっていなければならない。

市の将来成長のため他の町々とある程度の距離を置かねばならな い。市の中心から他の行政区域まで最低半径 1-2レグア legua（約 $5-10 \mathrm{~km}$ ）離さなければならない。距離を測る基点は, 教会前のプ ラサの中央に立てられた木の十字架とする。

新しい市となるべき街・区域には，増加する人口を見越して，十 分な住宅地や農地となるべき土地と, 農業・家蓄の飼料用の水源が なければならない。市の土地は市民のみの使用に限り，市民は遠隔 地に住んだり，土地を売買したり抵当に取ったりしてはならない。 もし住民が自分の土地を放棄した場合は，市の所有に戻り，市は他 の開犁者に与えることが出来る。市の経営や小教区司祭の出費を支 えるために，納税人口は，最低500人必要である ${ }^{31}$ 。」

市中心部の公共施設の建造, 土地の確保，市区域内での住宅地 · 農地計画が大きな三ヶ条である。補足として, 街路の配置・各戸間 の距離・火災防止のため各戸間の植樹などについても記述がある ${ }^{32}$ 。 特に町の中心部の計画についてはインディアス法と同じである。つ まり，フィリピンでも，中南米と同様のスペイン植民都市計画が推 し進められていたと考えられる。

マニラの石造建造物は, スペインやメキシコの建築をモデルとし ていた。教会建築に限らずフィリピンにおける建築計画は, イエズ ス会・フランシスコ会・アウグスティノ会などのスペイン人宣教師 たちが指導にあたった ${ }^{33}$ 。アウグスティノ会のスペイン本部は修道 士達に, 宣教前の心がま之・現地語の習得・協力体制などに加え， 建築計画について以下のように記している。

「町の構成：より効率的な社会発展のため, に, 住民は可能な限り従 来の点在した村々から町に集住させられるん゙きである。新しい町の 建設にあたっては, 交通の便のよい川辺か海辺を選択すべきである。 既存の開䅶された土地と淡水魚池に隣接し，集落が既に形成されて いるところも良い。宣教師の恒久的住居：1572年のアウグスティノ 会令により，宣教の拠点となる恒久的な司祭館を構えることが奨励
される。これにより司祭のいる中心町カべセラと，カべセラの周辺 村ヴィシタを行政地区の単位として定める。教育指導：宣教以外の 一般教育も修道会活動の一部であり, 修道院や司祭館は学校を併設 し，町の社会・文化的事業の中心となる ${ }^{34}$ 。」

教会や司祭館など宗教施設のあるプラサ周辺は，地域社会の中心 的役割を担う空間であった。宣教の為に「恒久的建造物を」という 項目は, 従来の木造高床式の建造物ではなく石造の教会や修道院の 建設を意味していた。

\section{3-2 ヴィガンの都市空間構成}

ヴィガンは現在，イロコス・スール州の州都である。ヴィガン市 の全面積は2,740へクタールで，そのうち $60.7 \%$ ぞ農地である（図 2 )。市全体は39のバランガイ行政区に分かれており，そのうち，市 街地バランガイ poblacion barangay 数は 9 , 農村バランガイ rural barangay 数は 30 である ${ }^{35}$ 。

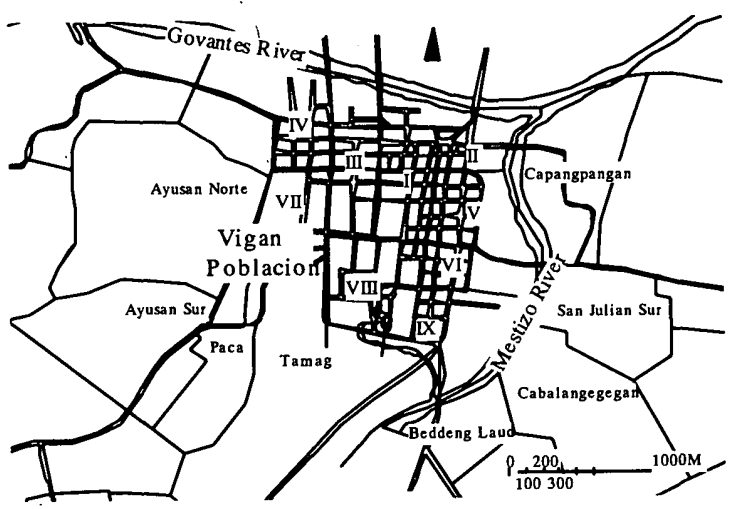

図 2 ヴィガンの行政単位：I 〜 IXはポブラシオン (市中心部) のバランガイ 番号を示す。

現在のヴィガン市の中心部を図 3 に示す。北をゴヴァンテス Govantes川, 東をメスティソ Mestizo川永によって区切られてい る。当初, 南東部に港と要塞が設けられその後, 北側に中心部が移 動したと考えられている。北側中央に, サルセド広場 Plaza Salcedo があり，その東に聖パウロ大聖堂，西に州庁舎，北に司祭館と修道 院，南に市役所などが配されている。大聖堂の南にはブルゴス広場 Plaza Burgos がある。近接して二つのプラサをもつスペイン植民都 市は珍しい。この二つの広場から，東西・南北にグリッド状に街路 が走るが, 入手した測量図によると街区規模, 街路幅員にはばらつきが ある。軸も南北軸から時計回りにおよそ14.6 16.5度の偏角を持つ。

フィリピン国立公文書館の記録には，1870年のヴィガン中心部に ついて「大聖堂の西には行政预 Casa Real とサルセドの像, 北には 司祭館を含む修道院 Convento と墓地，南には神学校 Seminario が ある。修道院の西には小さな家, 神学校の西には財政庁 Hacienda Publica, 警備士 Carabineros の宿舎, 市役所 Ayuntamiento Municipalがあった」と記されている ${ }^{37}$ ここの記録から，中南米にも見られ るスペイン植民都市の特徵であるプラサ・コンプレックスの形態を 保っていたことがわかる。

現在, ヴィガンは「“本物のフィリピノースペイン的”な公共建造物

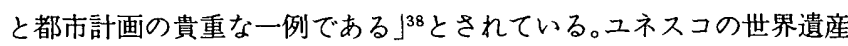
に登録された後, ヴィガン市は国内.・国外観光客向けのパンフレッ トに「国内で唯一保全されているスペイン植民時代の街であり，180 以上の歴史的住居と建造物が残っている」，とアピールしている39。 


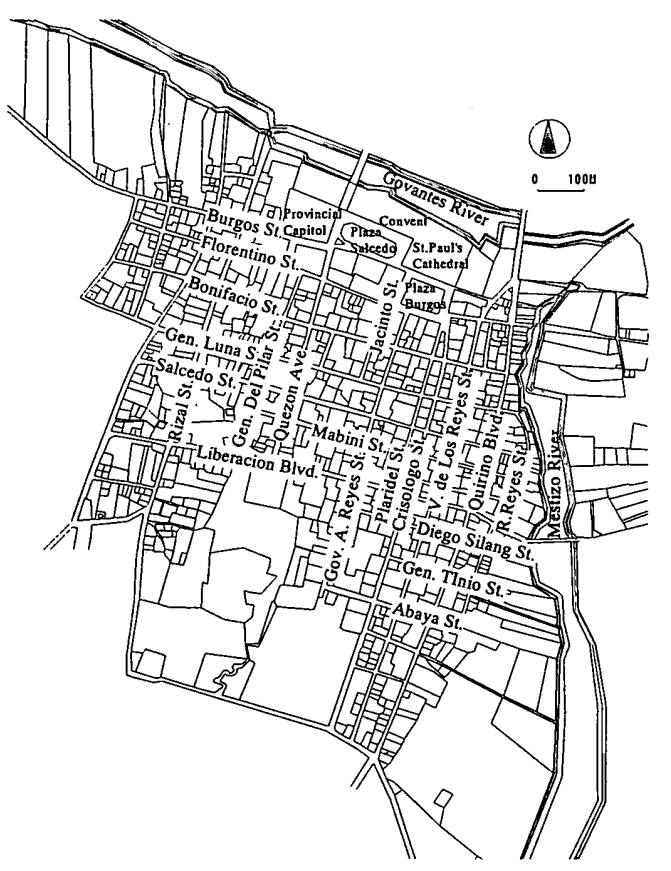

図３ヴィガン中心部の街路と街区割り

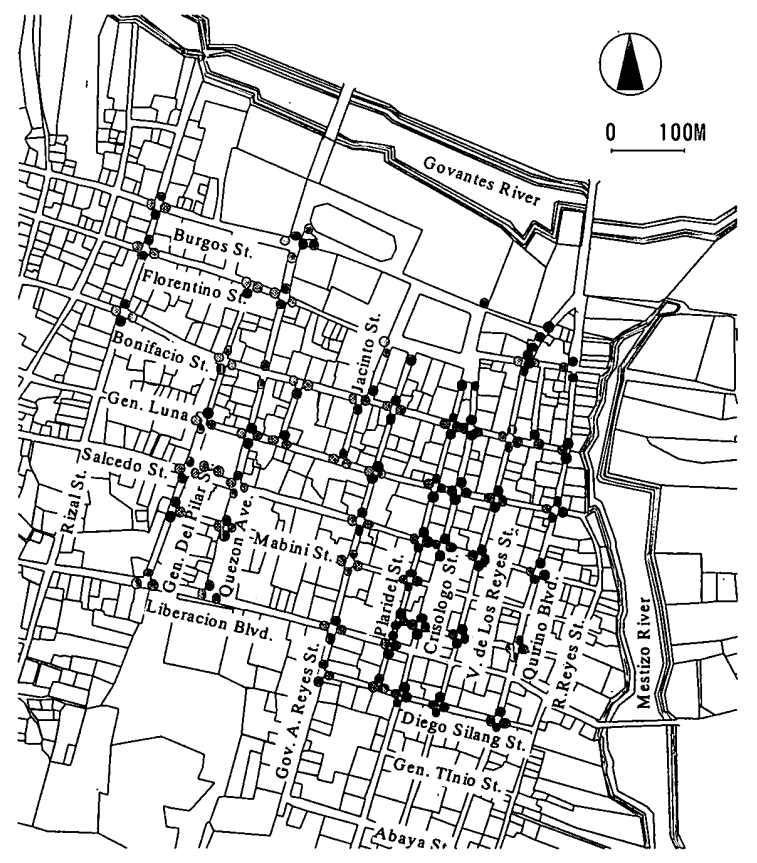

図 4 街路幅貝測定地点
伝統的なバハイ・ナ・バトは，街の東側に位置し，スペイン植民 地時代の中国系メスティソの居住区内であるクリソロゴ Crisologo 通り沿いに多く残されている。この通りは近年, 石畳敷きが再現さ れ，観光写真やフィリピン歴史映画のロケ地となっている。

\section{4. 街路体系と街区構成}

街区体系と街区構成について, 街路幅員, 街区規模, 街区の敷地 区分（宅地割り）を中心に考察したい。

上述のようにヴィガンには近接して二つの広場がある。広場は都 市計画の起点になったと考えられるが，二つの広場とも現況では正 確な矩形をしてはいない。大聖堂の入口が面するプラサ・サルセド は, 南・西の街路を含めずに, 東西が $148 \mathrm{~m}$ (南) $154 \mathrm{~m}$ (北), 南北が $64 \mathrm{~m}$ (東) $~ 72 \mathrm{~m}$ (西) である。大聖堂の南のプラサ・ブルゴスは，東 西南北の街路を含めて, 東西か $87 \mathrm{~m}$ (北) $120 \mathrm{~m}$ (南), 南北が $87 \mathrm{~m}$ (東) $95 \mathrm{~m}$ (西)である。インディアス法は, プラサの縦横の比を 2 : 3 が理想であるとする。また規模は, $300 ヒ^{\circ}$ エ pie ${ }^{40} \times 200$ ピエ(約 83.6 $\mathrm{m} \times 55.7 \mathrm{~m})$ 以上, 最大でも 800 ピエ $\times 300$ ピエ (約 $222.9 \mathrm{~m} \times 83.6 \mathrm{~m})$ 以下で，理想を 600 ピエ $\times 400$ ピエ $(167.2 \mathrm{~m} \times 111.4 \mathrm{~m})$ としている。 規模はともかく，プロポーションについては二つの広場とも理想に 則っているわけではない。

\section{4-1 街路幅員}

交差点を主に，183ケ所の街路幅員を測定した(測定個所一図 4)。 その結果を表 1 にまとめる。街路は現在，車道と歩道からなってお ク，敷地境界は必ずしも明確ではない。

ここでは建物と建物の間(内法)を街路幅員とし，両側歩道部分を 含めた幅を測定した。表 1 から分かるように，同じ通りでも街路幅 員は場所によってばらつきがある。当初は一定の街路幅員で計画さ れていたとしても，歴史的に変化してきたことが推測される。東の 南北街路キリ/Quirino 通りは緩やかにカーブしている。平均街路 幅員は $8.82 \mathrm{~m}$ であるが, $6.80 \mathrm{~m}$ から $10.60 \mathrm{~m}$ の巾がある。また，歷史
的街区の中心街路として石畳の街路整備が行われた馬車道クリソロ ゴ通りは, 平均 $8.70 \mathrm{~m}$ であるが, $7.12 \mathrm{~m}$ から $11.51 \mathrm{~m}$ までの巾があ る。

比較的グリッドが維持されているように見える三つの南北街路 V.ロスレジェス V.de Los Reyes 通り(平均 $8.46 \mathrm{~m}$, 最小 $6.30 \mathrm{~m}$, 最大 $11.04 \mathrm{~m}$, 以下同様), プラリデル Plaridel 通り $(6.97 \mathrm{~m}, 6.30 \mathrm{~m}, 7.51$ m), A.レジェス Gov.A.Reyes 通り (9.13m, $6.80 \mathrm{~m}, 12.43 \mathrm{~m})$ と五 つの東西街路ボニファシオ Bonifacio 通り $(10.32 \mathrm{~m}, 8.00 \mathrm{~m}, 14.49$ $\mathrm{m})$, ルナ Gen.Luna 通り $(8.80 \mathrm{~m}, 5.93 \mathrm{~m}, 12.09 \mathrm{~m})$, サルセド Salcedo 通り $(8.56 \mathrm{~m}, 6.31 \mathrm{~m}$,

$13.84 \mathrm{~m})$, マビニ Mabini 通 $\eta(8.99 \mathrm{~m}, 6.58 \mathrm{~m}, 11.92 \mathrm{~m})$, リベラシオン Liberacion 通 $\eta(11.30 \mathrm{~m}, 7.00 \mathrm{~m}, 16.49 \mathrm{~m})$ を見ても,ばらつきは大きい。 ただ，現在の目抜き通りで あるリサール通り，ケソン Quezon 通り，またリべラシ オン通りなどが車の交通のた めに拡幅されていることを考 慮し，比較的グリッドが維持 されているように見える旧市 街のみに着目して平均值を見 ると, 興味深い数值が得られ る。キリノ通りからリサール 通りまでの 9 本の南北街路の 平均は $9.33 \mathrm{~m}$, ハシント Jacinto 通り以西を除く 5 本

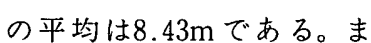
た，ブルゴス Burgos 通りか
表 1 街路幅員測定値（183地点）

潰 平均最大最小 南北道路名 地点数 [m] [m] [m] $\begin{array}{lllll}\text { Quirino } & 11 & 8.82 & 10.6 & 6.80\end{array}$ $\begin{array}{lllll}\text { V.de los Reyes } \quad 12 \quad 8.46 & 11.04 & 6.30\end{array}$ $\begin{array}{llllll}\text { Crisologo } & 10 & 8.78 & 11.51 & 7.12\end{array}$ $\begin{array}{lllll}\text { Plaridel } & 13 & 6.97 & 7.51 & 6.30\end{array}$ $\begin{array}{lllll}\text { Gov.AReyes } \quad 12 \quad 9.13 & 12.43 \quad 6.80\end{array}$ $\begin{array}{lllll}\text { Jacinto } \quad 4 & 9.38 & 10.35 & 8.45\end{array}$ $\begin{array}{lllll}\text { Del Pilar } \quad 10 \quad 9.76 & 12.32 & 6.72\end{array}$ $\begin{array}{lllll}\text { Rizal } & 7 & 10.23 & 11.40 & 8.60\end{array}$ 東西道路名

$\begin{array}{lllll}\text { Burgos } & 3 & 18.26 & 31.30 & 9.04\end{array}$

$\begin{array}{lllll}\text { Forentino } & 12 & 8.57 & 10.20 & 6.40\end{array}$

$\begin{array}{lllll}\text { Bonifacio } & 19 & 10.23 & 14.49 & 8.00\end{array}$

$\begin{array}{lllll}\text { Gen. Luna } \quad & 19 & 8.80 & 12.09 & 5.93\end{array}$

$\begin{array}{llllll}\text { Mabini } & 7 & 8.99 & 11.92 & 6.58\end{array}$

$\begin{array}{lllll}\text { Abaya } & 9 & 8.25 & 13.00 & 6.13\end{array}$ $\begin{array}{llllll}\text { Quezon } & 13 & 13.08 & 17.00 & 8.75\end{array}$

$\begin{array}{lllll}\text { Salcedo } & 14 & 8.56 & 13.84 & 6.31\end{array}$

$\begin{array}{llllll}\text { Liberacion } \quad & 8 & 11.30 & 16.49 & 7.00\end{array}$ 
らアバジャAbaya 通りまでの 8 本の平均は $10.38 \mathrm{~m}$, 広場北のブル ゴス通りとリベラシオン通り以南を除く 5 本の平均は, $9.05 \mathrm{~m}$ であ る。

この街路幅員のスケールをめぐっては以下の街区規模のスケール と共に考察したい。

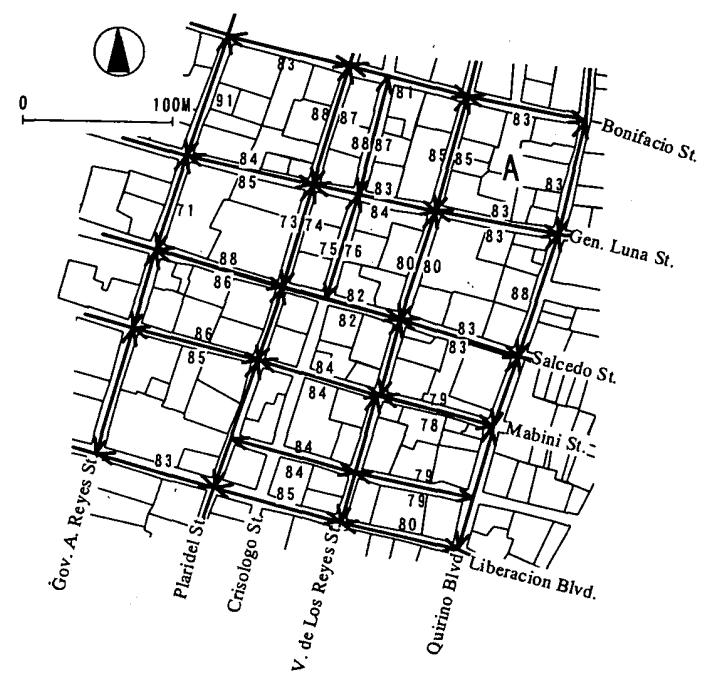

図 5 街区規模

\section{4-2 街区規模}

測量図（1/3000）をもとに，街区規模（街区を挟む街路の心々距 離）について計測した結果を示すと，図 5 のようになる。ばらつき はあるものの，ある程度一定の街区規模を確認できる。まず，目に つくのは南北街路キリノ通り，V、ロスレジェス通り，東西街路ボニ ファシオ通り，ルナ通りに囲われた一街区である(図 $5 \mathrm{~A}$ )。83m, $83 \mathrm{~m}, 83 \mathrm{~m}, 85 \mathrm{~m}$ (北，南，東，西：以下同様の表示)のほほ正方形 をしている。また，ル十通り，サルセド通りで囲まれたその南の街 区も $83 \mathrm{~m}, 83 \mathrm{~m}, 88 \mathrm{~m}, 80 \mathrm{~m}$ のほぼ正方形である。すなわち, 南北街 路キリノ通りとV.ロスレジェス通りの心々距離はほほ一定である。 ボニファシオ通りからリベラシオン通りまで北から $83 \mathrm{~m}, 83 \mathrm{~m}, 83$ $\mathrm{m}, 83 \mathrm{~m}, 83 \mathrm{~m}, 79 \mathrm{~m}, 78 \mathrm{~m}, 79 \mathrm{~m}, 79 \mathrm{~m}, 80 \mathrm{~m}$ で平均は $81 \mathrm{~m}$ である。 また，ボニファシオ通りとル十通りの心々距離の平均およびル十通 クとサルセド通りの心々距離の平均は，キリノ通りから A.レジェス

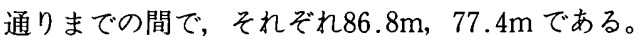

興味深いことにクリソロゴ通りを考慮せず，V.ロスレジェス通 クとプラリデル通りの間の心々距離を見るとボニファシオ通りから 南にリベラシオン通りまで， $81 \mathrm{~m} ， 83 \mathrm{~m}, 84 \mathrm{~m}, 82 \mathrm{~m}, 82 \mathrm{~m}, 84 \mathrm{~m}$, $84 \mathrm{~m}, 84 \mathrm{~m}, 84 \mathrm{~m}, 85 \mathrm{~m}$ である。

以上の概観を念頭にスペイン植民地で用いられた単位を検討する と，以下のような推論が可能となる。スペイン植民地関連の文献で 頻繁に用いられるのはレグア leguaである。トルデシリヤス条約 (1494)のポルトガルとスペインの分割線は, ヴェルデ岬諸島から 370 レグア西と決められた。また，中南米では100レグア毎，150レグア 毎の要塞, 町の建設が薦められている。秀吉の時代に日本に来た宣 教師の記録でもレグアが用いられている。しかし，レグアは長距離

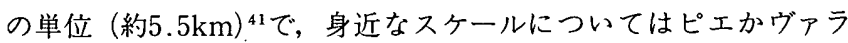
vara が用いられる。ピエは上で既に触れたが「足」を意味し，ほぼ フット（フィート）と同じである。ヴァラは「木組，足場」に由来
し，「細長い棒」を意味するが， 3 ピエの長さをいう。他にパルマ palma (「手のひら」)，ブラサ braza という単位が用いられるが，1 ヴァラは 4 パルマ, 2 ヴァラが 1 ブラサである。具体的には 1 ピエ= $0.2786 \mathrm{~m}, 1$ ヴァラ $=0.8359 \mathrm{~m}$ とされている ${ }^{42}$ 。フィリピンの建造物 計画において，これらスペイン人の用いた単位の中では，主にヴァ ラが使用されていたと言われている。

先に注目した正方形の区画は，ほぼ100ヴァラ四方である。また， 街路幅員はほぼ10ヴァラ程度となる。基本的に100ヴァラ四方を街区 の単位とし, 街路幅員10ヴァラを基本として計画がなされたのでは ないかというのが本稿で提出する仮説である。

\section{4-3 街区の敷地区分}

各街区がどのように宅地に区分されていたかは明らかでないが, 現況から検討してみたい。各街区の縦横が何分割されているか，す なわち通りに面した土地が何戸の宅地に分割されているかを，約 100 ヴァラの幅を持つボニファシオ通りルナ通り間，ル十通りサルセド 通り間，キリノ通りV.ロスレジェス通り間，V.ロスレジェス通りプ ラリデル通り間, プラリデル通り A.レジェス通り間について, 南北 ボニファシオ通りリベラシオン通り間, 東西キリノ通り A.レジェス 通り間の街区について見ると表 2 のようになる。

表 2、街区の繸横の分割数

\begin{tabular}{l|l|l|l|l|l}
\multicolumn{1}{r|}{ 分割数 } & 無 & 2 & 3 & 4 & 5 \\
\hline Bonifacio 通り Gen.Luna 通り間 & & 1 & 1 & 3 & 1 \\
\hline Gen.Luna 通り Salcedo 通り間 & 1 & 2 & 2 & & 1 \\
\hline Quirino 通り V.de Los Reyes 通り間 & & 1 & 8 & 1 & \\
\hline V.de Los Reyes 通り Plaridel 通り間 & & 1 & 8 & 1 & \\
\hline Plaridel 通り Gov.A.Reyes 通り間 & & 3 & 4 & 2 & \\
\hline 計 & 1 & 8 & 23 & 7 & 2
\end{tabular}

上記のように，三分割の例が極めて多いことが分かる。可能性と して, 街区を $3 \times 3$ の 9 分割する理念があったのではないかと考え られる43。すなわち，100ヴァラから街路幅員の計10ヴァラを引いた 90 ヴァラを三分割した 30 ヴァラ×30ヴァラの宅地に分割する計画理 念である。

以上の推測，仮説に対して，興味深い中南米の事例がある。図 6

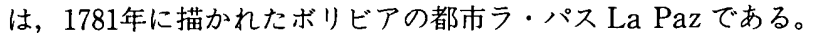

ラ・パスはヴィガンに先立つ1546年に建設されている。プラサ・ マヨールが中央に位置しているのは異なるが，二辺に川が接してい るのはヴィガンに似ている。ラ・パスの街区は一辺約 $84 \mathrm{~m} て ゙ あ り ，$ これは100ヴァラの近似值である。スペイン植民都市の街区規模は 100ヴァラであったという一例となる。

図 6 を見るとプラサ・マヨールの下 (北東) の街区が $3 \times 3$ の 9 分割である。しかし，他の分割パターンは様々である。整然とした 区割りとしては，もう一街区 9 分割の街区があり，他に $4 \times 4$ の 16 分割がある程度である。また，この絵が描かれた時点で建設時点か ら 200 年以上経っており，もともと 30 ヴァラ× 30 ヴァラが単位であっ たかどうかは不明である。

絵からは $4 \times 4$ の16の分割パターンもあったとも考之られる。U とつの根拠は面積の単位である。スペイン植民地において面積の単

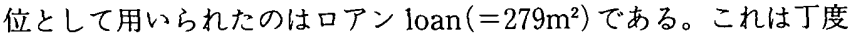




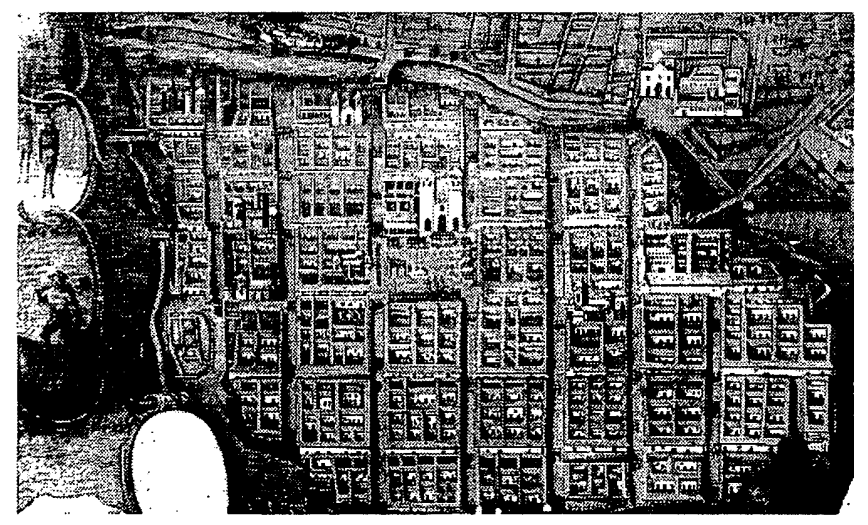

図 6 1781年のラ・パス （Kagan, Richard L. 2000)

20 ヴァラ× 20 ヴァラの面積である。即ち,もう一つの可能性として, 10 ヴァラ(街路幅員) +20 ヴァラ× $4+10$ ヴァラ(街路幅員) $=100$ ヴァラという分割が考えられる。一街区は16ロアンの面積を持つこ とになる。ただ，この場合，街区中央部へのアクセスの問題がある から, 中南米の都市図に多く見られるように, 街区をまず十字形に 分割する $(2 \times 2=4$ 分割 40 ヴァラ×40ヴァラ=4ロアン)パター ンであったと考えた方がいいだろう。

中心部(東西ボニファシオ通りからシラン D. Silang 通り, 南北キ リノ通りからA.レジェ通り)の敷地について, 全宅地の規模を測 量図から計測すると平均 $643.9312 \mathrm{~m}^{2}$ となる。ロアン単位の分布を見 ると，図 7 のうになる。2 ロアン前後のものが最も多いことが注 目される。また，4ロアン単位の分割も見られる。

測量図からは心々間を100ヴァラとして設定した可能性が高い。ナ イン・スクエア（9）分割を第1の仮説としたい。

\section{5.まとめ}

ヴィガンの街区体系・街区構成に関する以上の考察をまとめると 以下のようになる。

(1) ヴィガンの建設が開始された1572-74年は,フェリぺII世のイン ディアス法の出された1573年と同時期である。このインディアス 法は16世紀初頭からの植民統治経験の集大成である。従って,フィ リピンに1573年の法が即座に伝わらなかったとしても，スペイン 植民都市の構成原理が何らかの形で用いられた可能性は高い。

(2) ヴィガンの場合，プラサを近接して二つ持っており，中南米で 一般的な中央にプラサ・マヨールを持つ都市とは異なる。しかし， インディアス法も港湾都市の場合は港に接して広場を設けるとし

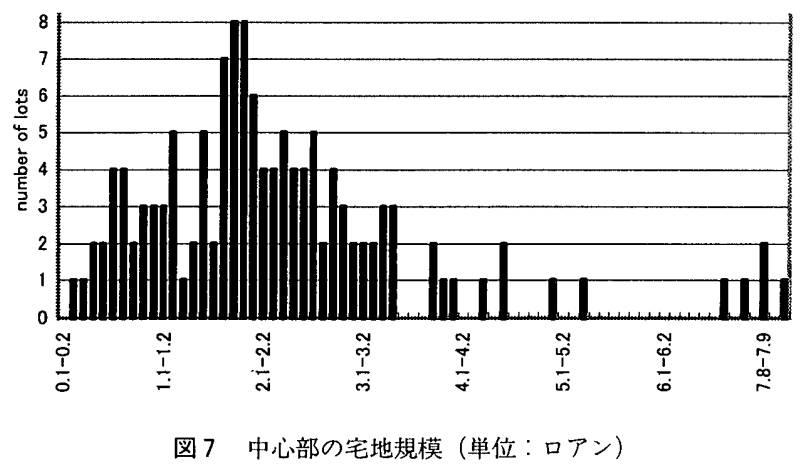

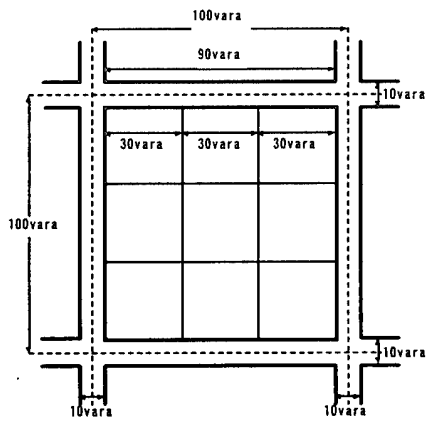

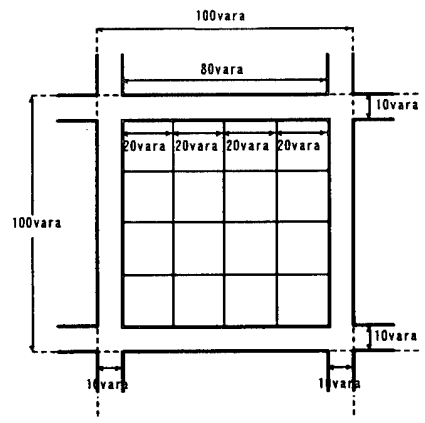

図 8 街区割りの概念図

ており，広場の規模やプロポーションも逸脱しているわけではな W。

(3) 現状の街路幅員，街区規模のばらつきは大きいが，旧市街の街 区規模が $80 \mathrm{~m}$ ～ $85 \mathrm{~m}$ の正方形をしていることが注目される。スぺ イン植民都市で用いられた単位ヴァラを元にすると, 街区は心々 で100ヴァラ四方，街路幅員は10ヴァラとしていたと考えられる。

(4) 各街区がどのように宅地分割されていたかについて，現況の宅 地割りをもとに考察すると街区の各辺は 3 分割される例が多く $3 \times 3$ のナイン・スクエアの分割が基本であったことが考えられ る。寸法体系としても，100ヴァラから街路幅員の計10ヴァラを引

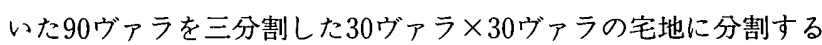
計画理念は考之やすい。

(5)しかし, 中南米の植民都市の場合， $2 \times 2$ の 4 分割が基本となっ ており，40ヴァラ×40ヴァラもしくは20ヴァラ×20ヴァラ（1ロ アン）が単位となった可能性もある。

以上の考察結果は，住居類型との関係において検討する必要があ る。バハイ・ナ・バトの類型と街区構成の関係については別稿とし たい。

註

1 植民都市坒間の系譜・変容・転成・保全に関する研究は〈支配↔一被支配〉 〈ヨーロッパ文明↔ $\rightarrow$ 着文化〉の二つを拮抗基軸とする都市の文化変容の 研究である。また実践的には，植民地期に形成された都市核の再開発が都 市計画上の課題になり，植民都市遺産を否定するのか, 継承するのかが大 きなテーマとなりつつある。この研究は，文部省科学研究費助成研究「植 民都市空間の系譜・変容・転成・保全に関する研究」(研究代表者布野修司, 1999-2001年度）の一環である。

2 マニラに建設されたスペイン人街。1645年には $5 \mathrm{~m}$ 厚の石造防御壁で囲ま れていた。

3 Leyes de Indias：インディアスと総称されたスペイン領アメリカの植民 地律法の総体を指し，法源はカスティーリヤ法と本国から発せられた植民 地のための諸立法から成る。植民地の経営には，既存の制度や法のみでは 不十分であり，新たな制度や機関が導入され，多くの法令が本国から発せ られた。1573年のフェリペII世によるインディアス法はこれらのうちのひ とつである。17世紀中ごろには既に40万件を超えており，1680年にこれら を編管したカルロスII世による「インディア、ス法集成」が公布された。新 大陸の富の開発とカトリックの布教という 2 大方針に集約されるが，多く の不備や久陷があり，論理的な体系を欠いていた。佐藤明夫「インディア ス法」『スペイン・ポルトガルを知る事典』平凡社, pp.50〜 51, 1999

4 夕ガログ語で「石の家」を意味し，スペイン植民期フイリピンの低地キリ ス卜教地域に流布した，一階石造・二階木造の都市住宅。現地住民・メキ シコ経由のスペイン人・中国人の技術が混合した様式で，現在は「フィリ ピン的な歴史住宅様式」とされている。

51505 ? -72スペインのバスコ地方出身。メキシコで植民地行政についた後, フィリピン諸島初代総督で先連都督 adelantadoの称号を有した。 
6 Antonio de Morga (1966)

7 plaza：スペイン語で「広場」の意味。ギリシャ語 platea「広い通り」, ラ テン語 platea「通り」より派生。

8 cabecera/poblacion：スペイン語で「首部・首都」の意味。地域行政の中 心となるスペイン植民都市で，市場・教会・市役所をもつ。

visita：スペイン語で「訪問·巡察」の意味。フィリピンでは司祭の在住 しない周辺村の意味で, cabeceraの教会の常任司祭が定期的に訪れた。 visita よりも更に小規模の集落は sitio と呼ばれた。

9 ヴィガンの名は, この地方の川辺に植生する葉の広い植物ビガン bigan (alocasia indica) に由来する。Foronda, A. Juan：The Establishment of the First Missionary Centers in Ilocos 1572-1612, Ilocos Review Vol. III, No. 1 \& 2, pp.1-75, 1971.1-12

10 Aluit, Alfonso J.: By Sward and Fire-the Destruction of Manila in World War II, 3 February-3 March 1945, Bookmark, 1995

11 エンコミエンダを得た征服者。エンコミエンダとはスペイン語で「委託」 を意味する。一定地域に住む先住民の労働力を使用する権利と, 彼らを保 護しキリスト教に改宗させる義務を，スペイン王権が私人に等託した制度 である。Justicia Mayorはスペイン語で「司法権の長」の意味。

12 サルセドが一度ヴィガンを離れたために，ヴィガンの設立は 1572 年と74年 の 2 説がある。

13 Baraganza（1971）。現在ヴィガンの「要塞・砦」の痕跡は見られない。 14 1494年のトルデシリヤス条約によっでスペインとポルトガルは新世界を分 割し，その領有権を獾得したが，同時にそこに住む現地住民をキリスト教 徒に改宗する義務をローマ教皇に負うことになった。Foronda（1971）

15 マニラ以外の地域ではスペイン人官吏の絶対数が少なく, ‘カトリック宣教 師が村や町の唯一のスペイン人であることが多かった。小教区教会の司祭 が，同時にその教区範囲の公務執行を行い，洗礼・堅信・結婚・死亡など， 教会の秘躦記録がそのまま人口記録や㷊史資料となっている。Cullinane, Michael : Accounting for Souls: Ecclesiastical Sources for the Study of Philippine

Demographic History, Population and History, Ateneo de Manila University Press, pp.281-346, 1998。本稿ではアウグスティノ修道会の保 管寸る資料を含めた，現代のイロコス地方アウグスティ/修道会士達によ る歴史資料 Ilocos Review Vol. III, No. 1\&2, 1971.1-12 参考にした。

16 スペイン語で「削減・制定」を意味する。南米のスペイン人入植地で先だっ て行われたレドゥクシオン(集落の数を減らし大きな街に集住させる計画) が,のちにフィリピンにも持ち込まれた。焼烟農業を主としていたフィリ ピンでは，思うよjに実現しなかった場合が多い。メキシコでのブルゴス 法（1512年）ではレドゥクシオン後インディオが再び離散するのを防ぐた めに, 古い村 puebloを差配することも定められていた。税·労働力の㩁取 とカトリック宣教のしやすさから、レドゥクシオンは押し進められた。

Cortes (1990)：Semo, Enrique, 原田金一郎訳 Historia del Capitalismo en Mexico，Los Origenes 1521-1763。『メキシコ資本主義史 その起 源」大村書店, 1994 ；山本徽「Reduccion」『ラテンアメリカを知る事典」 平凡社, $p 463 ， 1999$

17 タガログ語で「集落・街区」の意味。ムスリムやスペイン人到来以前から 存在したフィリピンの村落共同体の呼び名に由来し, 元々は首長 datu と 30-100家族からなる。スペイン人は barrioバリオと呼び名を変えたが, 1972年マルコス大統領戒㛜令体制下に再びバランガイと名づけられた。

18 菅谷成子「スペイン植民都市マニラの形成と発展」『アジアの大都市 [4] マニラ」日本評論社, pp21-47, 2001

19 Antonio de Morga (1966)

20 Parianはメキシコ系スペイン語の市・市場。中国人が商業に携わっていた ことからか。-cilloはスペイン語の縮小辞。

21 Sangleys はフィリピン在住スペイン人による中国人の呼び名。

22 King, Damaso Q. (1990)

23 King, Damaso Q.氏2000年 8 月31日インタビュー。ナトゥラレスであって も富裕層ならメスティソ地区に住むこともあった。メスティソ川より東の 市街にも中・下層メスティソが住んでいたと言われている。

24 Foronda (1971)

25 スペイン語で「区・地区」の意味。アラビア語のbarri「郊外の」より派生。 26 Brangaza (1971)

27 King (1990)

28 Mojares, Resil B: Casa Gorordo in Cebu-Urban Residence in a Philippine Province, Cebu Ramon Aboitiz Foundation, 1983; Zarag. oza, Ramon Ma: Images of Asia-Old Manila, Oxford University Press, 1990
2916 世紀末にメキシコ経由でフィリピンに来たアウグスティノ修道会士たち の出生地はスペイン本国であった。

Nieto, Marcelino: The Work of the Augustinians in Ilocos, Ilocos Review Vol. III, No. 1\&2, pp.166-226, 1971.1-12

30 Cortes (1990)

31 Ibid.

32 Ibid.

33 例えば代表的なサン・アグスティン教会 San Agustin（1607）などは, 16 世紀メキシコの教会・修道院建築の「正確な復元」を試みたものだとされ ている。Foronda (1986)

34 Nieto (1971)

35 Vigan Tourism Council, Vigan-A Unesco World Heritage Site, 2000

36 メスティソ川の名は, 中国系メスティソが多かったことに由来して，スぺ イン植民時代に付けられた。また，ゴヴァンテス川とメスティン川はアブ ラAbra 河の分流であり，河口付近につくられた街である。King (1991)

37 King (1990)

38 Baraganza (1971)

39 Vigan Tourism Council (2000)

401 pie は約 1 フィート $=0.278635 \mathrm{~m}$ ( 12 プルガダ pulgada (インチ))。pie は「足」, pulgataは「親指の大きさ」を意味する。

411 legua $=33331 / 3 \mathrm{braza}=5572.705 \mathrm{~m}$

42 石井米雄監修『フィリピンの事典』同朋舎, 1992。ピエは尺, ブラザが尋 と考之ていい。

43 現在 2 分割， 4 分割であっても，地図を見ると「元々 3 分割であった宅地 の一つをさらに 2 で割ったために, 現在 4 分割であるもの」や「元々 3 分 割であった宅地 2 つ分を，現在 1 つに併合しているために 2 分割であるも の」が見受けられる。

\section{主要参考文献}

[1] Antonio de Morga, 神吉敬三訳 Sucesos de las Islas Filipinas. 「フィ リピン諸島史』岩波甾店, 1966 (1609)

[2] Baraganza, Jose Vicente: To the End of the World, Ilocos Review Vol. III, No. 1\&2, pp.135-165, 1971.1-12

[ 3 ] CEDEX : La Ciudad Iberoamericana, Biblioteca CEHOPU Madrid, 1987

[4] CEDEX : La Ciudad Hispanoamericana El Sueno de un Orden, CEHOPU Madrid, 1997

[5] Cortes, Rozarion Mendoza: Pangasinan 1801-1900-The Beginning of Modernization, New Day Publishers, 1990

[6] Foronda Jr., Marcelino A. : Insigne Y Siemple-Essays on Spanish Manila, De La Salle University, 1986

[ 7 ] Javallana, R, Reyes, E.V. and Zialcita F.N. Filipino Style, Edition Didier Millet, 1997

[8] Kagan, Richard L.: Urban Images of the Hispanic World 1493-1793,. Yale University Press, 2000

[9] King, Damaso Q.: Ciudad Fernandina O Vigan, Vigan Convent Archives, 1990

[10] King, Damaso Q. : Parish Church and Cathedral of St. Paul, Vigan, The Ilocos Review, Vol. 23, pp.2-32, 1991

[11] McCoy, A.W. and de Jesus E.C. : Philippine Social History-Global Trade and Local Transformation, Ateneo de Manila University Press, 1982

[12] Rabang-Alonzo, Fatima Nicetas: An Inventory of 120 Ancestral Houses in Vigan, Ilocos Sur, Philippines, Save Vigan Ancestral Homes Association INC, 1996

[13] Rabang-Alonzo, Fatima Nicetas: Conservation of the Historic Core of Vigan, Master of Architecture Thesis, University of the Philippines Diliman, 1990.3

[14] Reed, Robert R. : Colonial Manila-The Context of Hispania Urbanism and Process of Morphogenesis, University of California Press, 1978

[15］鈴木静夫『物語フィリピンの歴史」中央公論社, 1997

[16] Zialcita, Fernandez N. and Tinio Jr., Martin I. : Philippine Ancestral Houses

（2001年 7 月10日原稿受理，2001年11月27日採用決定） 